\title{
Shona Writers' Vision of the Liberation Struggle: A Name-Centred Approach
}

\author{
Godwin Makaudze1, Enna Sukutai Gudhlanga ${ }^{2}$ \\ ${ }^{1}$ Great Zimbabwe University, Masvingo, Zimbabwe \\ ${ }^{2}$ Zimbabwe Open University, Harare, Zimbabwe \\ Email: makaudzegodie@gmail.com, gudhlangaes@gmail.com
}

Received 8 July 2015; accepted 24 July 2015; published 29 July 2015

Copyright (C) 2015 by authors and OALib.

This work is licensed under the Creative Commons Attribution International License (CC BY). http://creativecommons.org/licenses/by/4.0/

(c) $\underset{\mathrm{EY}}{\mathrm{i}}$ Open Access

\section{Abstract}

The liberation struggle is such an historic event in Zimbabwean history to an extent that even today, constant reference is made to it in a bid to remind and challenge the whole nation to safeguard its cause. Efforts have also been made to enlighten the new generation on the rationale, experiences and gains of this struggle, with intent to make them appreciate the sacrifices made by the gallant fighters who made such possible. As such, many history books, novels, poems and drama texts have been published, all conveying this significant aspect in history. Although a lot of analyses have been devoted to how Shona literature captures this significant event, focus has been on the truthfulness of lack of it as conveyed through the experiences in the given texts. Interestingly, Shona novelists, in this case Choto, have explored the Shona tradition of capturing and conveying historical events through naming. Shona people have, since time immemorial, used the technique of naming to document and to remind society of significant events in the past. In Vavariro (1990), Choto exploits this Shona tradition by giving his characters names that illuminate the experiences, pain, joys and aspiration of the participants in the second Chimurenga which ultimately brought independence to Zimbabwe. The paper is therefore an examination of how successful the author uses the naming technique in telling the Zimbabwean story during and after the war of liberation. It uses the socio-historical approach as its theoretical grounding.

\section{Keywords}

Liberation Struggle, Shona Novel, Shona Names, Gains

Subject Areas: Literature

\section{Introduction}

Earlier writers of Shona literature always celebrated and portrayed the liberation struggle as one in which guer- 
illas/freedom fighters always outwitted the enemy. They portrayed the liberation struggle as a pleasing experience demonstrating the ingenuity of the freedom fighters. Literature produced soon after independence which included the poetry anthologies Nduri dzeZimbabwe [1] Nduri dzeNhango dzomuZimbabwe [2], and novels like Hamutyinei’s Zvakanga Zvakaona muZimbabwe [3] and Nyawaranda's Mutunhu une Mago [4] eulogised and celebrated the struggle and, to these writers, there was nothing more that the nation wanted after attaining independence. These early writers of the struggle demonstrated that a new Zimbabwe had come and that independence was an end to people's suffering not a means through which the new government was supposed to bring an end to people's suffering. The struggle was waged in the context of deprivation, acute unemployment, segregation, unjust land policies, ill-treatment of the majority of blacks and it was fought with the aim of improving the people's lives and bringing back the heritage that had been stolen and to build a new Zimbabwe for all. These early writers did not focus on the context in which the struggle was waged, but only marvel at the coming of independence.

Through the naming technique, the author Choto in his novel Vavariro [5] tries to capture the history, experiences and the ultimate gains or lack thereof of Zimbabwe's liberation struggle. The writer makes use of names that talk, showing that Shona naming is a unique comprehensive discourse [6]. The writer uses names that according to Isaacs act as badges [7] of the experiences and aspirations of those who participate in the struggle. Unlike earlier novelists, Choto does not eulogise the liberation struggle but demonstrates that it is a difficult period in which both the freedom fighters and the Rhodesian forces suffer great losses.

\section{Theoretical Grounding}

The socio-historic approach informs this paper. It states that literature does not operate in a vacuum, but is influenced by the society from which it emerges. This enables the researchers to examine and evaluate a work of art in terms of the social conditions under which the art was produced [8]. In this case, the theory helps the researchers to understand Choto's portrayal of the experiences of the Zimbabwe's liberation struggle through the naming technique. Choto's novel focuses on The Second Chimurenga (which brought independence to Zimbabwe), waged after the World War II, between 1963 and 1980. In depicting the events and the outcomes of this liberation struggle Choto makes use of what Kahari [9] calls "deterministic names"; that is names that convey the situations, experiences and aspirations of the bearers.Fighters of the liberation struggle of Zimbabwe did not use their proper names, but assumed pseudo-names which were in line with both the Shona naming system and the events of the struggle. Thus, using the socio-historical approach allows for Choto's characters' names to be understood in the context of Shona people's history of naming and the events of the Second Chimurenga in Zimbabwe.

In the process of explaining names of Choto's characters, the paper unavoidably illuminates the pains, joys and gains or lack thereof of the liberation struggle. This includes what the freedom fighters and peasants who fought the war have gone through, dating from the time of the Second Chimurenga which ushered in Zimbabwe's independence to the newly independent state. By documenting all these significant phases and events in history, the author shows that among the Shona giving names is "the same as writing history books" [10].

\section{The Novel, Vavariro}

The story centres on VaChimoto and other parents together with freedom fighters and the mujibhas and chimbwidos (young men, boys and young women and girls who ran errands in the war) who whole-heartedly support and participate in the gruesome struggle for independence in which they have so many losses to count. Having presented the efforts, determination and aim of the various participants, the author proceeds to examine the rewards of independence. He makes use of significant names, which include VaChimoto, Tumirai, Danai, Torai (take, a name of a mujibha), Rambanai (Divorce each other, the name of a beer hall in Harare) and Garikai (live well, the name of Tumirai's son), among others. These names mainly depict the experiences, pains and aspirations of the struggleas well as the extent of empowerment brought about by independence.

\section{VaChimoto}

In the novel, the bearer of the name is one of the elders in the village where the war of liberation is fought. The name Chimoto has several meanings including fire, chaos and trouble. The struggle had several fires experi- 
enced by both Black Africans and the coloniser. People's homes were torched and burnt down, so was their livestock. Inversely, many city buildings, fuel tanks and even white men's farms were also torched by guerrillas and mujibhas and chimbwidos as they fought to exterminate colonial rule. Chimoto again conveys a chaotic situation in which things are haphazard, with no order or tranquillity. The name posits that colonisation brought about chaos in African people's lives; there was disorder and disharmony. Through this name, the author demonstrates that there was mayhem (chimoto) when people of African descent in colonial Rhodesia lost their land to the white settlers, with history showing that land was shared equally between races, with white settlers who comprised a mere $5 \%$ of the total population occupying the best and very productive lands and the indigenous population who comprised 95\% occupying barren and unproductive land [11]. The land which they lost was a source and guarantor of their lives. As a result African people's lives were in shambles and, in a bid to regain their lost heritage (through waging the struggle), there was further chaos and disharmony implied by the character's name.

Also the severe beatings, maiming, killings and burning down of people's property and wealth which characterised the liberation struggle are all captured in this name. The author shows that VaCharira's homestead was torched and his livestock burnt. Many freedom fighters and war collaborators (mujibhas and chimbwidos) were bombed and shot to death. At the same time whites also lost their kith and kin, and infrastructure worth thousands of dollars was destroyed. For example, Tsitsi a female war collaborator was sent and bombed a white-only hotel in Salisbury. In this regard, the author demonstrates that the period of the liberation struggle was characterised by chaos, disproving earlier writers that portrayed the liberation struggle as a period in which the enemy suffered and blacks were hardly on the receiving end.

Through the name VaChimoto the author demonstrates that both parties endured pain and suffered heavy losses vindicating Ngubane's [12] observation that naming is a very serious cultural affair among Africans.

\section{Kufa}

The same suffering conveyed through the name Chimoto is also conveyed through the name Kufa which literally means to be dead. The liberation struggle ushered so many deaths to the enemy, the villagers and freedom fighters. Many villagers and their livestock were also killed by the Rhodesian forces. Some were killed for supporting the guerrillas with food, clothes and shelter while others were killed for having sons or daughters that fought to remove colonial rule. In addition, many freedom fighters lost their lives, being shot, bombed and even hanged by the Rhodesin forces. These deaths have even led the Zimbabwean government to declare the $11^{\text {th }}$ and $12^{\text {th }}$ of August every year as Heroes and Defences commemoration day. The idea is to remember the many lives lost as people fought to liberate Zimbabwe.

The name Kufa also brings out a truism about the struggle, that there were also "struggles within the struggle," what Nzongola-Ntanjala [13] describes as revolution and counter-revolution as some blacks fought against their own kindred. In other words, the struggle was not a Black people versus White people type of the struggle. Rather, there were also some blacks who sided with, and fought side by side with the settler. These people caused so many deaths to their black counterparts, and were also in turn killed by the freedom fighters. VaBango's children who included Peter worked for, and fought on behalf of the colonial government. He caused the torturing and torching of VaChimoto's family, domestic animals and homestead. In turn, he and his father, who was a sell-out were also killed by freedom fighters.

\section{Tapera}

This literally means "we are finished". A lot of lives were lost during the struggle (many guerillas and war collaborators died at the hands of the enemy) vindicating why the liberation struggle is referred to as "the hard won struggle". Independence did not come on a silver platter but several lives were lost and several homesteads razed to the ground. This vindicates Mandela's book title, "No easy walk to freedom". In other words, it was not easy for African countries to gain freedom. It took many lives and weapons to bring independence.

The name also captures that Blacks' lives were finished. Black people's lives were finished in many respects. Firstly, during the colonial period, the people lost vast tracts of arable land which was fenced off into farms by the coloniser. The owners of the land were pushed into barren soils. Bannerman [14] describes such areas as "more like graves than places to live in". The same scholar explains that it was actually easier to die than to earn a living by tilling such a wasteland. Blacks were squeezed in rocky soils and could not shift to new land once the 
one in use was exhausted. What Mogona [15] says of the South African situation equally applies to colonial Rhodesia, that:

My people could no longer heal the land. They could not restore it when it was exhausted. The law forbade them to move pasture. A person's place of dwelling became their place of dying...Fenced in and forced to till exhausted land, we could not feed ourselves. But you see, even that were no accident. The no-colour people had planned it all.

As land, the source of livelihood was forcibly taken from them more calamity befell them. They lost several lives through such Acts as the Land Husbandry Act, where they were not allowed to keep more than 8 beasts per household. Thus Black people's being was shaken and threatened to the core. Realising that they were finished, the people waged an armed struggle to overturn the injustices of the colonial era. In the struggle, also they lost a lot of livestock to since they slaughtered them as a means of sustaining the struggle, providing food for the freedom fighters.

Unlike earlier authors like Nyawaranda in Mutunhu une Mago who portrays the liberation struggle as being sustained by the cattle that were stolen from the white man's farm, Choto demonstrates that even the black man's cattle and other forms of livestock were also slaughtered in order to feed the freedom fighters who popularised the myth that "gandanga haridye derere" (a freedom fighter does not eat okra). Such myths encouraged peasants to offer their livestock to the freedom fighters because eating vegetables symbolised by okra was believed to result in the defeat of the freedom fighters by the enemy. So the name also symbolises that even black's livestock in general got finished. Above all, the name "Tapera" means "when we were finished," capturing that independence came when blacks were finished, when they were incapacitated, having lost most of their wealth.

\section{Jeri}

The issue of suffering is also conveyed through the name Jeri which means "prison". So many blacks were imprisoned, some without committing any crimes but for political reasons. Most of these political prisoners spent a lot of years in prison at Hwahwa and Gonakudzingwa without trial but were just being incarcerated so that they lose all hope of ever gaining their freedom. Most of the people who are declared national heroes in today's Zimbabwe are those who at one time were imprisoned by the settler regime.

In the novel, Tapera was imprisoned and ill-treated and was released after he had lost so much weight (kupera) which was also captured by his name which illustrated ill-treatment meted out on blacks in jails. The suffering which he undergoes, and which is implied by his name vindicates Ngubane's [12] assertion that one cannot separate a name from the person because the two are one. Whereas the European concept is that the name refers to a person, the African concept demonstrated here is that the name is the person [16].

Apart from physical imprisonment experienced by the people, colonial laws which the people fought to remove were forms of imprisonments for the people. They were forced off their land and disallowed from locating to better places. They again were not allowed to keep beasts that exceeded eight. They were forced to pay an assortment of taxes, dog, and poll and hut tax. Also, so many curfews were pronounced during the struggle, with people barred from moving at certain times, or into certain places. All these were various forms of imprisonment experienced by Blacks.

\section{Tsitsi}

The name means "mercy", and it demonstrates that the success of the struggle partly hinged on the mercy of the peasants, parents and war collaborators who willingly assisted the freedom fighters. The help offered by the peasants is aptly captured in Mao Tse Tung's words who said, "the people are the sea and the guerillas are the fish swimming in the sea". This demonstrates that these other people made it possible since the guerillas' strength lied in the masses, without whom there would have been no success story to the liberation struggle. The peasants had mercy towards the guerrillas; that is why they did not sell them out to them enemy.

The masses also made it possible for the guerillas to participate successfully; they oiled the wheels of the liberation struggle through many merciful deeds. The masses/peasants provided lots of food in the form of beasts that were slaughtered, cooking for the guerillas and they in a way waged the war with cooking sticks. They were also the "ears and eyes" of the freedom fighters and warned them against impending danger; they also surveyed 
places before the guerillas arrived, they carried their luggage, gave them clothes, blankets and shoes, did the washing and ironing of their clothes and above all gave them medical attention when they fell sick or were hurt during battles.

Through the name Tsisi, Choto demonstrates that it is mythical to believe that it is only those who held guns who fought the struggle. Rather, there were many unsung heroes of the liberation struggle. Staunton [17] in Mothers of the Revolution brings to the fore the role played by women whom she dubs the "mothers of the revolution", who helped the guerillas in various but very crucial ways which made it possible for the war to be won. The name thus makes it ironic to consider as heroes only those who held guns during the struggle, ignoring the majority who fought the battle at many other fronts.

\section{Danai}

Tsitsi is also complemented by the name Danai (love each other), which is a plea for blacks to love each other and do away with the acts of selling out. It is a plea to such people like VaBango who sold out and worked with the Rhodesian forces to desist from such retrogressive acts. Even the likes of Peter Bango who worked in the Rhodesian police force were being urged to unite and love their own people and work against the enemy, not siding with the enemy.

The name also means "call out to" someone (kudana) and it demonstrates that so many people were called to participate in the struggle, and these include ancestors, parents, war collaborators (mujibhas and chimbwidos) and the guerillas themselves who left their homes and went for training in Mozambique, Zambia, Tanzania and many other countries. Having been "called out to," the people responded very well leading to the successful waging of the struggle and the attainment of independence. In this regard, just like in others, the character's name is a walking political, social and economic statement [6].

\section{Tumirai}

The name means "send". It has a holistic approach to the events during the struggle and it captures that several people "were sent" for training to fight against the enemy. In the novel, the parents were asked to send their young boys and girls to the freedom fighters so that they are trained into being the eyes and ears of the fighters, and they response was overwhelming. The name further attests to the sending of young recruits to neighbouring countries for military training, for example Tapera and other chimbwidos and mujibhas who were sent to Mozambique.

It also captures the plea for parents to sent (kutumira) necessities such as food, clothes and moral support for the struggle. The name also conveys the many cases where fighters and war collaborators were sent to fight and destroy the enemy. For example, Tsitsi was sent with a bomb to Salisbury to destroy a white-only hotel, a job she undertook diligently. Also, the likes of Tapera and Jeri and others were sent to Dereck's farm to poison his livestock and they also were successful.

The act of fighting by shooting the enemy is conveyed by this name. Bullets and bombs were sent to the enemy's territory and infrastructure. All this was meant to destroy the enemy. Pongweni [18] asserts that by looking at such names one cannot but be struck by the wealth of information, historical, descriptive, picturesque and human which they provide.

\section{VaCharira (LHHH)}

It means they will suffer and surrender. The name aptly captures the pain that was inflicted on the enemy in a bid to make him surrender. Acts of plunder as undertook by Tsitsi who went and bombed and all-white hotel and the vandalism at Derek's farm by Jeri and others were all meant to make the white man surrender. The name was also an assurance to the freedom fighters and others that despite the cruelty and mighty of the enemy he will ultimately surrender. This became real when the white settlers finally gave in to the Lancaster House Conference that ultimately ushered Zimbabwe's independence. They had indeed suffered and surrendered.

\section{Torai}

The name means "take" or "repossess". At one level, it is expressive of the act of taking weapons to fight the enemy. Having been marginalised by the colonial government, Blacks took up arms to fight the exploitative 
system. This was also conveyed through a popular song of the struggle, "Mbuya Nehanda":

Mbuya Nehanda kufa vachitaura shuwa

Shoko ravo ravakataura, "Tora gidi uzvitonge"

Grandmother Nehanda died having said

Her word, which she said was, "Take up arms and liberate yourself"

In response, freedom fighters, chimbwidos, mujibhas and the parents all took up various arms to face the enemy, guns, bombs, cooking sticks, among others. Some of these weapons were taken from friends of the struggle, such countries as Russia, China, Cuba, Mozambique, Zambia and others while others were taken from the enemy.

The name Torai, which also means "repossess" also suggests that blacks should take back their lost heritage, the land. It captures the aspirations of the struggle; that of repossessing what belonged to them. Land was so integral to Black people's survival that losing it was akin to losing a livelihood, and getting land back was repossessing life. Paton's [19] words equally apply here, that:

Land is life, deny them land deny them life. Guard it, keep it and care for it, for it guards men, keeps men, cares for men. Destroy it and man is destroyed.

The name Torai conveys the aspirations of Blacks wanting to be independent. It was a wish of the struggle to bring to the people total empowerment. People were promised that everyone would have access to good and fertile land and good jobs among other things [20]. The name was a forecaster to the reversal of all the colonial injustices.

\section{Rambanai}

It is the name of a beer hall in Mbare and not a character's name. It means "divorce each other". The name captures the division that later emerged with the advent of independence where the ones seemingly united forces later went their separate ways when the time to enjoy the fruits of the struggle had come; the participants were no longer singing from the same hymn sheet. As Cabral [21] observes, although people may seem united during the struggle, internal contradictions are likely to emerge at independence.

After the war, Jeri becomes a Major in the army and rises through ranks. Ultimately, he buys a piece of land in Christone Bank and practices intensive market gardening [22], something he could never have done during the colonial period. The same applies to Tumirai who also becomes a Member of Parliament for Uzumba. VaChimoto witnesses a number of significant changes in Tumirai's life. He now puts on very expensive suits, owns two cars, one for himself and the other for his wife, owns a very huge and beautiful house in one of the low density areas with very attractive lawn, has two workers-a gardener and a housemaid [23]. His house is well furnished, with bathing tubs that have phones and fixed mirrors. Independence has significantly improved his way of life. Blacks now own property in low-density suburbs, areas previously deemed fit for whites only. Paradoxically, VaChimoto meets and shares beer with a colleague whose place of residence is a shack at the bus terminus [24]. Whilst some former fighters are integrated into the Zimbabwe National Army, others like Kufa are excluded on health grounds [25]. Ironically, with the same ailment that marks him out at independence, he had been able to fight and endure all the hardships of the war such as hunger, thirst, diseases, fatigue, and travelling long distances. With that ailment, he contributed to the coming of independence. One wonders how the ailment that had not jeopardized his fighting for independence can now disenable him to enjoy the gains thereof.

Again, whereas the struggle had promised the likes of VaChimoto and VaCharira that they would occupy Derek's farm, with the advent of independence, they are harshly driven out of the farm through the use of dogs. Independence thus created a barrier between the leaders and those who are led. During the struggle VaChimoto could see Tumirai anytime he wanted but after independence he realises that he cannot see him without an appointment. Whereas he has shared beer with a friend who stayed in a shack in MbareVaChimoto realises that Tumira now lives in one of the low density suburbs of Harare in Gunhill with two cars, two house workers, fitted mirrors in his bathrooms and even telephones and he says to himself, "mupfana uyu wakarwira zviripo" (this young man benefitted a lot out of the war) and he fails short of saying, "vamwe Havana chavakarwira" (others fought for nothing), showing that those who once loved each other during the liberation struggle have now di- 
vorced each other as conveyed through the name Rambanai.

The name thus captures that soon after the war there are classes that have emerged among the blacks themselves, the very same classes they tried to get rid of by waging the war of liberation.

\section{Conclusion}

Earlier writers of Shona literature write largely celebrating and portraying the liberation struggle as one in which guerillas/freedom fighters are invincible. They portray the liberation struggle as an enjoyable moment where freedom fighters and the grassroots came together to sing and dance, enjoying the successes on the battlefield. This is evidenced through the anthologies Nduridze Zimbabwe and Nduri dzeNhango dzomuZimbabwe, and novels like Nyawaranda's Mutunhu une Mago and Hamutyinei’s Zvakanga Zvakaoma muZimbabwe. Choto departs from the earlier crop of writers on Zimbabwe's Chimurenga war as he goes beyond mere celebration to posing questions about the sweetness of the struggle as well as whether it betters people's lives. Through the use of names Choto captures the experiences, joys, worries, gains and lack thereof of the liberation struggle. The way the names are used by the writer shows that Shona "names are social documents" [26]. The naming technique allows him to cast light upon all that happened and reveal all that lay hidden and [27]. Through it, he moves away from marvelling at the exploits of the fighters and the advent of independence to question whether the liberation struggle was all laughter and happiness and also probes what independence brings to the people. As a result, he stands distinctively even from his contemporaries like Chimhundu [28] who presents the struggle as a total flop for failing to better the lives of people and Makari [29] who also sees the liberation struggle as having brought a very good life to the participants. These other two writers distort reality by showing independence as a total failure on one hand (as in Chimhundu's novel), and a total success on the other (as in Makari's novel) when in fact it is characterised by both successes and failures which Choto highlights in his novel through the naming technique. The portrayal by Choto has helped in shaping contemporary Zimbabwean people's consciousness as they now question and challenge the new black leaders to be responsible and to meet the promises of the struggle.

\section{References}

[1] Chitepo, H., Mutswairo, S., Kumbirai, J. and Hodza, A. (1981) Nduridze Zimbabwe. Longmans, Harare.

[2] Haasbroek, J. (1983) Nhango dzeNduri dzemuZimbabwe. Mambo Press, Gweru.

[3] Hamutyinei, M.A. (1984) Zvakanga Zvakaoma muZimbabwe. Mambo Press, Gweru.

[4] Nyawaranda, V. (1985) Mutungu Une Mago. Longman Zimbabwe, Harare.

[5] Choto, R. (1990) Vavariro. Baobab, Harare.

[6] Makondo, L. (2010) An Exploration of Prerequiste Shona Naming Factors. South African Journal of African Languages, 30, 154-169.

[7] Isaacs, H.R. (1975) Idols of the Tribe: Group Identity and Political Change. Harper: Harper and Row Publishers, New York.

[8] Welleck, R. and Warren, A. (1973) Theory of Literature. Penguin Books, Harmondsworth, 113-120.

[9] Kahari, G. (1986) Aspects of the Shona Novel. Mambo Press, Gweru.

[10] Zvarevashe, I.M. (1998) Dzinzarava Goverava Chirumhanzuna Mutasa. Mambo Press, Gweru.

[11] Batezat, E. and Mwalo, M. (1989) Women in Zimbabwe. Sapes, Harare.

[12] Ngubane, S.E. (1998) The Significance of the Social Code in Relation to Names and Naming of African Children. In: Chiwome, E.M. and Gambahaya, Z., Eds., Culture and Development: Perspectives from the South, Mond Books, Harare, $178-181$.

[13] Nzongola-Ntanjala, J. (1987) Revolution and Counter-Revolution in Africa: Essays in Contemporary Politics. Zed Books Ltd., London and New Jersey.

[14] Bannerman, J.H. (1970) The Land Apportionment Act: A Paper. OUP, London, 103.

[15] Mogona, S. (1992) The Scars of Umlungu. New Internationalist, April 1992, pp. 9.

[16] Koopman, N. (1986) The Social and Literary Aspects of Zulu Personal Names. Unpublished Master's Thesis, University of Natal, Durban.

[17] Staunton, I. (1990) Mothers of the Revolution: Oral Testimony of Zimbabwean Women. Baobab Books, Harare. 
[18] Pongweni, A.J.C. (1983) What’s in a Name? Mambo Press, Gweru.

[19] Paton, A. (1976) Cry the Beloved Country: A Story of Comfort in Desolation. Penguin Books, London, 7.

[20] Choto, R. (1990) Vavariro. Baobab, Harare, 91-93.

[21] Cabral, A. (1973) Return to the Source. Monthly Review Press, New York and London.

[22] Choto, R. (1990) Vavariro. Baobab, Harare, 148.

[23] Choto, R. (1990) Vavariro. Baobab, Harare, 156.

[24] Choto, R. (1990) Vavariro. Baobab, Harare, 153.

[25] Choto, R. (1990) Vavariro. Baobab, Harare, 147.

[26] Evans-Pritchard, E.E. (1939) Customs and Beliefs Relating to Twins among the Nilotic Nuer. Uganda Journal, 3, $230-$ 238.

[27] Thiongo, N. (1982) Devil on the Cross. East African Publishers, Nairobi.

[28] Chimhundu, H. (1991) Chakwesha. College Press, Harare.

[29] Makari, C.S. (2003) Magambae Chimurenga: Josiah Tungamirai. Mambo Press, Gweru. 